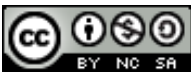

https://doi.org/10.31743/abmk.12459

KIRYL SYTSKO* - MIŃSK (BIAŁORUŚ)

\title{
PARAFIA PODWYŻSZENIA KRZYŻA ŚWIĘTEGO W LACHOWICZACH W OPISIE WIZYTACYJNYM Z 1745 ROKU
}

\begin{abstract}
Streszczenie
W publikacji przedstawiono wizytację parafii pw. Podwyższenia Krzyża Świętego w Lachowiczach z dnia 21 lipca 1745 r. Jest to jej pierwsza lustracja po remoncie kościoła zniszczonego w 1706 r. podczas wielkiej wojny północnej. Świątynia kilkakrotnie była trawiona przez pożary, została skonfiskowana po powstaniu styczniowym przez władze carskie oraz zniszczona przez władze Białoruskiej Socjalistycznej Republiki Radzieckiej w 1960 r. Aktualnie kościół pw. Podwyższenia Krzyża Świętego, podobnie jak parafia, nie istnieje. Przedstawiony tekst wizytacji został opatrzony komentarzem naukowym i tekstowym. Przedstawiono również metodykę pracy nad rękopisem.

Słowa kluczowe: Lachowicze; Parafia Podwyższenia Krzyża Świętego; wizytacje; Antoni Józef Żółkowski; sufragania białoruska
\end{abstract}

\section{Wstęp}

Wizytacja w parafiach diecezji wileńskiej, która rozpoczęła się w 1745 r., a zakończyła w 1754 r., odbyła się z inicjatywy biskupa sufragana białoruskiego (tac. Suffraganeus Albae Russiae) Antoniego Józefa Żółkowskiego. Został on powołany na synodzie wileńskim 11 lutego 1744 r. ${ }^{1}$ i chciał zapoznać się ze stanem powierzonej mu części diecezji. Według niektórych badaczy wizyta bpa A. Żółkowskiego zmieniła praktyki wizytacyjne. W szczególności nowym elementem

* Kiryl Sytsko - dr historii, kandydat nauk historycznych, Centralna Biblioteka Naukowa NAN na Białorusi

e-mail: kirylawolny@gmail.com

https://orcid.org/0000-0003-3633-9797

${ }^{1}$ Synodus Dioecesana Vilnensis ab Illustrissimo, Exellentissimo ac Reverendissimo Domino D. Michaele Joanne Zienkowicz Dei \& Apostolicae Sedis Gratia episcopo Vilnensi, Vilnae: Typis Mandata, MDCCXLIV [1744], s. 153. 
był niezwykle szczegółowy model opisu działalności gospodarczej parafii, który daje możliwość analizy jej stanu majątkowego w najdrobniejszych szczegółach ${ }^{2}$.

Wizytacja objęła tylko 40 parafii, podczas gdy w sufraganii białoruskiej od 1744 r. było blisko 180 kościołów ${ }^{3}$. Lustracja została podzielona na pięć etapów $(1745,1746,1748,1749,1754)$ i odbyła się w miesiącach letnich i jesiennych.

Nie wszystkie akta zachowały się w księdze wizyt z lat 1745-1754, co jednak nie przeszkadza w rekonstrukcji historycznej pierwszego etapu. Dane o wizytach w 1745 r. przedstawiono w poniższej tabeli.

Tabela 1. Pierwszy etap wizytacji z 1745 r.

\begin{tabular}{|c|c|c|}
\hline Lp. & Data & Parafia \\
\hline 1. & 21 lipca 1745 r. & Darewo \\
\hline 2. & 21 lipca 1745 r. & Lachowicze \\
\hline 3. & 25 lipca 1745 r. & Swojatycze \\
\hline 4. & 26 lipca 1745 r. & Kleck \\
\hline 5. & 29 lipca 1745 r. & Iszkołdź \\
\hline 6. & 1 sierpnia 1745 r. & Mir \\
\hline 7. & 5 sierpnia $1745 \mathrm{r}$. & Niehniewicze \\
\hline 8. & 20 sierpnia $1745 \mathrm{r}$. & Słonim \\
\hline 9. & 27 sierpnia $1745 \mathrm{r}$. & Łukonica \\
\hline 10. & 29 sierpnia $1745 \mathrm{r}$. & Dereczyn \\
\hline 11. & 30 sierpnia $1745 \mathrm{r}$. & Mosty \\
\hline 12. & 31 sierpnia $1745 \mathrm{r}$. & Różana \\
\hline 13. & 1 września 1745 r. & Lack \\
\hline 14. & 3 września 1745 r. & Kamionka \\
\hline 15. & 10 września 1745 r. & Jeziory \\
\hline 16. & 11 września 1745 r. & Wasiliszki \\
\hline 17. & 12 września 1745 r. & Wawiórka \\
\hline 18. & 13 września 1745 r. & Żyrmuny \\
\hline
\end{tabular}

Źródło: Narodowe Archiwum Historyczne Białorusi (dalej: NAHB), sygn. 1781-27-213, Buзиты костёлов Западной Беларуси 1745, k. 271-274v.

Jak wynika z księgi wizytacji, parafię pw. Świętego Krzyża w Lachowiczach zlustrowano w pierwszym etapie jako jedną z pierwszych (21 lipca 1745 r.). $\mathrm{Pu}-$ blikacja wizytacji parafii w Lachowiczach jest początkiem projektu wydawania materiałów dotyczących wizytacji biskupa sufragana białoruskiego A.J. Żółkowskiego i będzie kontynuowana zgodnie z chronologią lustracji kościołów (przygo-

${ }^{2}$ W.F. Wilczewski, Wizytacje generalne diecezji wileńskiej w XVII-XVIII w. Ewolucja problematyki, „SOTER”, (2010) №2 35(63), s. 103.

${ }^{3}$ Synodus Dioecesana Vilnensis, s. 175-194. 
towano również do publikacji akt kościoła w Darewie). Projekt jest realizowany w ramach zaplanowanego przez autora tematu na lata 2021-2026.

Parafia Podwyższenia Krzyża Świętego w Lachowiczach powstała dzięki fundacji hetmana wielkiego litewskiego Jana Karola Chodkiewicza i jego żony Zofii Chodkiewicz z Mileckich w 1602 r. ${ }^{4}$ Parafia została uposażona we wsie Potapowicze oraz Kaniuszki, folwark Krzeczetowo, młyn na rzece Trościance, a także jurydykę w Lachowiczach (razem 50 włók ziemi) ${ }^{5}$. Później pojawiły się kolejne zapisy funduszowe: 12 maja $1681 \mathrm{r}$. ks. Władysław Snarzki, proboszcz parafii Lachowicze (na zakrystianina); 25 listopada 1687 r. Maciej Borzymowski, miejscowy szlachcic; 24 marca 1688 r. ks. Kazimierz Dębowski, proboszcz parafii Lachowicze (na „bakałarza w retoryce umeiętnego i chorał znaiącego").

Kościół, zbudowany z drewna, spłonął w $1660 \mathrm{r}$. podczas oblężenia miasta przez wojska rosyjskie ${ }^{7}$. W 1706 r. świeżo odrestaurowana świątynia została ponownie zniszczona, tym razem przez wojska szwedzkie - odbudowano ją dopiero w 1741 r. (tym samym wizytacja z 1745 r. jest pierwszym dokumentem poświadczającym stan własności parafii pw. Podwyższenia Krzyża Świętego po wzniesieniu nowego budynku świątyni). Kolejny raz kościół spłonął podczas konfederacji barskiej w latach 1768-1772, po czym został odbudowany w 1803 r. przez książąt Massalskich $^{8}$, tym razem z kamienia. W 1831 r. został poświęcony, ale nie konsekrowany 9 . Po powstaniu styczniowym 1863-1864 kościół został skonfiskowany i przekazany Cerkwi prawosławnej. W 1873 r. wybuchł kolejny pożar, który spowodował znaczne zniszczenia świątyni. Odbudowano ją w stylu neorosyjskim w tzw. „Мураўёўку”10. Budynek dawnego kościoła został ostatecznie zniszczony przez Sowietów w 1960 r., kiedy wysadzono go materiałami wybuchowymi. Dziś parafia pw. Podwyższenia Krzyża Świętego w Lachowiczach nie istnieje.

Księga zawierająca wizytację parafii Lachowicze (NAHB, sygn. 1781-27-213) jest w stosunkowo dobrym stanie. Grzbiet i boki są postrzępione. Na wewnętrznej stronie okładki widoczne są ślady kleju powstałe w wyniku złej jakości uzupełnienia. Tekst nie jest wyblakły. Niektóre arkusze papieru przez wilgoć utleniły się. Większość aktów w księdze charakteryzuje się brakiem pieczęci. Pieczęcie bisku-

\footnotetext{
${ }^{4}$ NAHB, sygn. 1738-1-1, Актовая книга 30.05.1793-23.12.1794, k. 95.

${ }^{5}$ П.Ю. Булаты, Уладанні і гаспадарчая дзейнасиь каталіцкага касиёла на землях Ляхавіцкага графства (XVII-XVIII стст.), Весці БДПУ Серыя 2, (2018) №2, s. 98.

${ }^{6} \mathrm{NAHB}$, sygn. 937-3-8, Инвентарь Ляховиикого костёла и прихода 1828, k. 10v-11.

${ }^{7}$ Булаты, Уладанні і гаспадарчая дзейнасиь, s. 99.

${ }^{8}$ П.Ю. Булаты, Першая візітаџыя мураванага касиёла у Ляхавічах (1804 год), “Долгий XIX век” в истории Беларуси и Восточной Европы: материалы III международной конференции, сост.: С. Ф. Шимукович, Минск 2019, s. 38.

${ }^{9}$ NAHB, sygn. 937-3-11, Инвентарь Ляховичкого костёла, прихода и фольварков 1831, k. 2.

${ }^{10}$ Мураўёўкі - cerkwie, które powstały z inicjatywy generał-gubernatora wileńskiego Michaiła Murawjowa po powstaniu w latach 1863-1864 na terenie białorusko-litewskich prowincji Cesarstwa Rosyjskiego z celem zakorzenienia prawosławia.
} 
pie zachowały się (lub zostały pierwotnie umieszczone) tylko w dokumentach parafii w Lacku (pieczęć woskowa) ${ }^{11}$, Rosi (pieczęć tłoczona) ${ }^{12}$, Iszczołnie (pieczęć woskowa $)^{13}$.

Tekst wizytacji parafii pw. Podwyższenia Krzyża Świętego został napisany ręką dwóch pisarzy. Osoby te mają radykalnie różne pismo odręczne, a także stopień nacisku pióra na papierze. Pierwszym z nich jest Benedyct Nornicky / Benedykt Nornicki (proboszcz parafii Lachowicze), który jest autorem tekstu wizytacji po łacinie. Przestał pisać ją w sekcji „Obligationes”. Drugi skryba, który pozostał nieznany, zaczął układać tekst wizytacji w nowy sposób, w języku polskim, powtarzając niektóre fragmenty z tekstu ks. B. Nornickiego.

W trakcie przygotowania publikacji przyjęto następujące zasady edycji tek$\mathrm{stu}^{14}$. Gramatykę, ortografię i inne cechy tekstu pozostawiono bez zmian i dostosowania do współczesnych reguł języka (np. Swięty zamiast Święty, ołtarż zamiast ołtarz). Ze względu na to, że część tekstu łacińskiego jest następnie przekazywana w języku polskim, nie dokonywano thumaczenia tych fragmentów na język polski.

Wszystkie ligatury są renderowane za pomocą kursywy (na przykład: Albae Russiae). Indeksy górne i dolne są umieszczone na linii bez dodatkowych symboli i komentarzy. Wszystkie skróty, a także brakujące słowa zostały ujęte w nawiasach kwadratowych [ ]. Skróty liczb porządkowych nie są ujawniane. Zawijanie części słowa do innej linii jest wyświetlane za pomocą znaku |. Te fragmenty tekstu, które zostały już zacytowane dosłownie, są pomijane i zapisane przy użyciu nawiasów klamrowych i wielokropka $\{\ldots\}$. Oznaczenia numerów arkuszy w oryginalnym źródle podano przed początkiem tekstu każdego arkusza w nawiasach trójkątnych $<>$. Fragmenty tekstu i słowa, które skryba podkreślił dużym naciskiem pióra, zostały podane pogrubieniem. Słowa i wyrażenia podkreślone przez skrybę są wyróżnione pogrubioną kursywą.

Przedstawiony tekst wizytacji został opatrzony komentarzem naukowym i tekstowym. W szczególności zwrócono uwagę na przekreślenia, plamy, osobliwości pisania poszczególnych słów, kierunek tekstu. Skomentowano błędy w datowaniu dokonane przez pisarza. Uaktualniono położenie geograficzne osad, nazwy rzek i miejscowości. Dodatkowo wyjaśniono miary, wagi i objętości. Wszystkie osoby występujące w tekście otrzymały krótkie biogramy. Podczas ich tworzenia wykorzystano informacje z projektu „The Hierarchy of the Catholic Church"15.

Edycja źródła została dokonana w według przepisów: Метадычныя рэкамендаџы да публікащы лачінскіх дакументай XIII-XIVcmст, склад. Алесь Жлутка,

${ }^{11}$ NAHB, sygn. 1781-27-213, k. 85.

${ }^{12}$ Tamże, k. $175 \mathrm{v}$.

${ }^{13}$ Tamże, k.184.

${ }^{14}$ Метадычныя рэкамендацыі да публікацьіі лацінскіх дакументаў XIII-XIVстст, склад. Алесь Жлутка, Мінск 2005; Метадычныя рэкамендаџыi па публікаџылі польскамоўных дакументаў па гісторыі Беларусі XVI - першай паловы XIX cm, склад. Аляксей Шаланда, Мінск 2012.

${ }^{15}$ The Hierarchy of the Catholic Church. Current and historical information about its bishops and dioceses, https://www.catholic-hierarchy.org/ (dostęp: 18.03.2021). 
Мінск 2005 (Zalecenia metodyczne dotyczace publikacji dokumentów tacińskich z XIII-XIV wieku, komp. Aleś Żłutka, Mińsk2005)oraz Meтадычныя рэкамендацыi па публікаиыі польскамоўных дакументай па гісторыі Беларусі XVI - першай паловы XIX cm, склад. Аляксей Шаланда, Мінск 2012 (Zalecenia metodyczne do publikacji polskojęzycznych dokumentów dotyczacych historii Białorusi w XVI pierwszej połowie XIX wieku, komp. Aliaksiej Shalanda, Mińsk 2012).

\section{Akt wizytacyjny parafii Podwyższenia Krzyża Świętego w Lachowiczach z dnia 21 lipca 1745 roku}

$<8>$

VISITATIO $^{16}$

Ecclesiae Lachovicensis

Sub Titulo S[ancte] Crusis Erectae

ab Ill[ust]r[issi]mo Excell[entissi]mo ac R[everen]d[issi]mo D[omi]no Antonio Josepho Żołkowski Dei et Apostolica Sedis gratia Episcopo

Allaliensi, Suffraganeo Albae Russiae, Praelato Decano Cathe|drali, Vicario in Spiritualibus, et Officiali G[e]n[era]li Vilensi

EXPEDITA

Anno D[omi]ni 1745. Mense Julio, Die 21.

Ecclesia haec noviter sub titulo S[ancte] Crucis erecta Sumptibus Perllris $\mathrm{R}$ [evere]n[dissimo] D[o]mi[no] Joannis Lopacinski ${ }^{17}$, Canonici Viln[ensi] et de reliquo moderni Recto|ris, in qua Suffitus Superior ex afseribus dedolatis compactis Sulpra trabes cernitur. Pavimentum ex lateribus planum, fenestrae vitri boni decem, Porta cum duplici janua, et seratura, Supra at|rium duae Jurres cum Crucibus deauratis afseribus contectae desu|per, Indultum habetur, ex quo Ecclesia nondum consecrata. Habel quoque Indulgentias pro festo S[ancti] Annae.

Altare majus opera Seuptoria extructum in una Contignatio|ne, cum mensa murata, et gradibus tribus, in hoc Altari Imago Crucifixi D[omi]ni sculpta, in vertice Imago DEI Patris inter nubes itidem sculpta. Circa Imaginem Crucifixi tres statuae. Una Beat[issi]mae Virginis, 2da S[ancte] Joannis, 3tia S[ancte] Magdalenae. In mensa habetur Portatile consecratum ab Ill[ust]r[issi]mo E[xcellentissimo] [ac] R[everendissimo] D[omino] Constantino Brzostowski ${ }^{18}$ Ep[isco]po Viln[ensi]. Cui inclusae sunt Reliquiae S[ancti] ${ }^{19}$ Pij et Eutichij m[onumentu]m. Portatile hoc integrum 3plici mappa adornatum, In me|dio mensae Crux Missae lignea, cum Imagine Crucifixi D[omi]ni sculpta, ad pedem Crucifixi reperitur Canon Missae, et duae minores tabellae in lateribus cum Evan|gelio S[ancte] Joannis, et

\footnotetext{
${ }^{16} \mathrm{~W}$ prawym górnym rogu drugą ręką dodaje się Lachowicze.

${ }^{17}$ Jan Dominik Łopaciński (1708-1778) - kanonik wileński (1732); duchowny sekretarz wielki litewski (1755-1762); biskup żmudzki (1762-1778).

${ }^{18}$ Konstanty Kazimierz Brzostowski (1644-1722) - pisarz wielki litewski (1671-1684); biskup smoleński (1685-1687); biskup wileński (1687-1722).

${ }^{19}$ Skrót podaje się jako $S S$.
} 
Psalmo Lavabo ubi etiam appensum manutergium, et pulvinar pro Missali habetur, ac campanula. Tabernaculum in eodem altari arte Sculptoria elaboratum in quo S[ancti]s[sim] um Sacramentum conserva|tur in Pyxide argentea cum operculo et Cruce tota deaurata, ciu substerni|tur Corporale mundum, Ibidem reperiuntir diae pyxides parvae argentea intus deauratae pro portando Ven[erabilis] Sacramento ad infirmos, ad quas haben|tur in Sacristia Bursae Stolis afsutae.

Altare 2dum a pariete ad Cornu Epistolae arte Sculptoria cum una Con|figuratione eleboratum in qua habetur Imago S[ancte] Thadei picta, in mensa lignea habetur Portatile consecratum ab IIll[ust]r[issi]mo E[xcellentissimo] [ac] R[everendissimo] D[omino] Alexandro Horain ${ }^{20}$ Ep[isco]po Hiranensi Suffraganeo Samogitae Anno D[omi]ni 1743 cui inclusae sunt Reliquiae S[ancti] ${ }^{21}$ Benigni ${ }^{22}$, Eutichij, et ex 10000 Martyrum $^{23}$. Sunq hic omnia Requisita. Hac duo Altaria cum Presbyterio distiqvuntur ab alijs cancellis.

$<8 \mathrm{v}>$

Altare 3tium extra cansellos a pariete ad cornu Evangelij arte seul ptoria cum 2bus contignationibus elaboratum, partim deauratum, par|tim variis coloribus depictum, in 1ma contignatione Imago S[ancte] Antonij cum parvulo Jesu. In 2da Imago S[ancte] Casimiri. Et hic sunt omnia Requisi|ta ad Missam praeter Portatile quod vetustate destructum erat, ideoq ab altari remotum.

Altare 4tum itidem extra cancellos a pariete ad cornu Epistolae arte Sculptoria extructum partim deauratum, partim varijs coloribus de pictum cum 2bus contignationibus, in prima Imagines $3 \mathrm{~S}$ [ancte] Annae, $\mathrm{B}$ [eatis]s[i]mae et Jesu parvilu, in altera Imago ab Ill[ust]r[issi]mo E[xcellentissimo] [ac] R[everendissimo] $\mathrm{D}$ [omino] Casimiro Brzostowski, cui inclu|sae sunt Reliquiae $\mathrm{S}[\operatorname{ancti}]^{24} \mathrm{Pij}$ et Eutychij m[onumentu]m. Et hic sunt omnia Requisita.

Baptisterium opera lignifabri elaboratum, in eo fons in vase stanneo cum operculo ibidem stanneo, repletus aqua munda in Vigilia Pentecostes consecrata, ibidem ampulla vitrea pro fundenda aqua, et vasculum cum $\mathrm{Sa}[\mathrm{nc}]$ te Benedicto vitreum. In vertice Baptisterij Crux lignea. Ibidem prope fon|tem habetur armariolum cum clausura et inscriptione: Olea Sacra quae in vase stanneo in eodem conservatur armariolo, renovata hoc anno, uti ex scheda Vise Custodis Cathedralis deducitur.

Suggestus in pariete ad cornu Evangelii habetur firmus, arte lignifabri ela|boratus, sine ullis picturis et Culmine, gradibus 4 ascenditur.

Confessionalia reperiuntur duo: Unum a sinistra parte, alterum a dextra opere lignifabri facta, in qiubus sunt lamina perforata, et crates in fenestellis.

${ }^{20}$ Aleksander Kazimierz Horain (1685-1774) - sufragan żmudzki (1731-1765), archidiakon wileński (1737) biskup tytularny Hirina (Byzacena).

${ }^{21}$ Skrót podaje się jako $S S$.

${ }^{22}$ Benigna z Wrocławia (XIII wiek) - męczennica i błogosławiona. Zginęła podczas najazdu Tatarów w $1259 \mathrm{r}$.

${ }^{23}$ Oznacza to 10000 męczenników. Byli to żołnierze rzymscy, którzy nawrócili się na chrześcijaństwo i zostali za to ukrzyżowani na górze Ararat.

${ }^{24}$ Skrót podaje się jako $S S$. 
Chorus habetur unus pro Organis et terra ad semiparietes elevates, in quo Organum parvum vulgo Pozytyw licet non pridem reparatum, tamen ob vetusta|tem sibillat, Libri ibi reperiuntur hi: Graduale, Antiphonarium, Psalterium, Pro|cessionale, Agendae majores duae, sed hi Libri omnes antiqui, Novi autem diffici|les sunt ad procurandum, ex eo, quod non imprimantur Vilnae.

Sacristia ad cornu Evangelii ad quam ianua bona cum seratura interio|ri et exteriori, in qua fenestra una sine cratibus, Suffitus ex afseribus dedolatis supra trabes compactis, Pavimentum simplex. In parte primaria Mensa, in qua ornatur Sacerdotes pro Missa, et Officiis Divinis, Supra Armariola pro afser|vandis: Monstrantia, calicibus, bursis, velis, pallis, corporalibus, ubi etiam re|peritur vasculum cum hostiis aenum, Crux parva, crux item major gestatoria tempore Processionum, Circa januam labrum cum operculo stanneum, Manu|tergium ex utraque parte pensile.

\section{Argenteria}

Tabernaculum Monstratorium argenteum in forma veteris normae cum Cruce et Melchisedech ${ }^{25}$ pro recipienda Hostia partim deauratum, Vitrum ex utraque parte nitidum.

Pyxis in qua conservatur Ven[erabilis] Sacramentum recenter addito plus argen|ti comporata cum operculo et Cruce tota deaurata.

Calices totaliter deaurati 2 Unus antiquus, alter novus.

Intus deaurati 3 omnes novi.

Patenae totaliter deauratae 2.

De super deauratae 3 omnes novae.

Pyxides parvae ad Infirmas 2 recenter ex tabellis comparatae

Crux argentea cum Reliquijs S[ancti]

Pacificale parvum de novo restauratum.

Vestis argentea S[ancte] Thadaei cum Cirigulo deaurato et linea argentea.

Vestis arg[entea] S[ancte] Annae et Parvuli Jesu, Sceptrum.

Vestis Parvuli Jesu ad S[ancte] Antonium. Cirigulus cum globulis et Colopediis argentis ibidem.

Radiola argentea circa Caput Crucifixi D[omi]ni.

Claves arg[entea] tres.

Corona arg[entea] deaurata cum 3bus Corallis haec ob velustatem destruitur.

Corona arg[entea] deauratae minores sex, ex his aliquae sine Cruce.

Corona arg[entea] non deaurata una.

Coronae $\arg$ [entea] minores quatuor.

Effiqies S[ancte] Spiritus arg[entea].

Imago B[eatis]s[i]mae ad 3 partes cubiti cum Veste argentea partim deaurata.

Radiola ad caput S[ancte] Thadaei.

Thuribulum cum catenulis, et navicula cum cochleari argent.

${ }^{25}$ Melchisedech - postać biblijna, król Szalemu. 


\section{Vota Srebrne}

\begin{tabular}{|l|c|}
\hline Tablica spora cum effiqie S[więty] Antonij w kwiaty wybijana z trzema lancuszki & 1 \\
\hline Tablic item w kwiaty wybijany dwie, z Herbem Misztoldowa trzecia & 3 \\
\hline Item w kwiaty wybijana iedna & 1 \\
\hline Tabliczek na rysowaniu pozłacanych dwie & 2 \\
\hline Tabliczka sporsza z obrazem S[więtego] Antoniego iedna, mnieyszych cztyry & 5 \\
\hline Tabliczek cum effiqie B[eatis]s[i]mae osim, cum effique Xti iedna & 9 \\
\hline Tabliczek z Imieniem Jezus dwanascie & 12 \\
\hline Z roznemi osobkami pięc & 5 \\
\hline Z literami trzy & 3 \\
\hline Z oczyma dwie & 2 \\
\hline Z wyraźeniem konika iedna & 1 \\
\hline Serduszek z Imieniem Jezus siedm & 7 \\
\hline Rączek dwie & 2 \\
\hline Konikow dwadziescie pięc. Wolik ieden & 26 \\
\hline Orderek pozłacany ieden & 1 \\
\hline Korona cierniowa srebrna z gałązkami pozłocanemi & 1 \\
\hline Summa sztuk wszystk[ich] & 81 \\
\hline Korali więszych Sznurkow Sześć & 6 \\
\hline Przeplatowany paciorkami Srebr[nymi] ieden & 1 \\
\hline Korali drobnych Sznurkow dwaziescie dziewięc & 29 \\
\hline Robnieyszych z perełkami Sznurek ied & 37 \\
\hline Summa Sznurkow & \\
\hline
\end{tabular}

\section{Kruszec}

Cynowych lichtarzow Ołtarzowych 28

Krzyż stary ieden

Łoka cynowy z łyżeczką stara

Ampułek nowych sześć

Jaca o nich iedna

Lawaterz do umywania rąk

Mosięznych lichtarzykow małych stołowych dwa

wielki na Pashał do Ołtarza ieden.

Trybularz ieden

Lampa iedna. Miednica, Bezmian.

$<9 \mathrm{v}>$

Miedzianych kotlow chorowych dwa

Kociołek na wodę swięconą

${ }^{a}$ Herb Lubicz. 
Brytwan do topienie wosku

Lyszka spora nowa

Spiżowych Dzwonow wielkich dwa, trzeci srzedni, czwarty mnieyszy

Dzwonek przy Zakrystyi ieden

przy Oltarzach cztyry

w Plebanij na zywołanie Chłopca ieden

Żelazo do pieczenia Opłatkow.

Kozyczki do wyrzynania Hostyi

Cyrkilik do robienia Komikantow.

\section{Paramenta}

\section{Ornaty Biate}

1. Lamowy z kolumną niebieską adamaszkową w kwia|tach złocistych z stułą y Manipularzem stary.

2. Lamowy z kolumną zieloną aksamitną stary.

3. Pułjedwabny w paski z kolumną Bantajerem wyszy|waną z stuła y Manipularzem.

4. Pułjedwabny takoż w paski z kolumną Łudanową galon bantajerowy z stuła y Manipularzem.

\section{Czerwone}

5. Aksamitny Pónsowy z kolumną Lamową białą z stułą y Manipularzem.

6. Partyrowy w rozne kwiaty z kolumną atłasową bia|ła hoftakowaną z stuła y Manipularzem.

7. Lamowy karmazynowy z kolumną adamaszkową niebieską w kwiaty złociste malenkie $\mathrm{z}$ styłą y manipularzem.

8. Aksamitny haftowany złotem z kołumną srebrną z stułą z manipularzem.

9. Aksamitny galon złoty koło kolumny reperatione indigo.

10. Łudowany z kolumną Lamową stary.

11. Adamaszkowy z kolumną niebieską.

12. Lamowy z kolumną aksamitną nazbyt stary.

13. Partyrowy w kwiaty złociste z kolumną aksamitną.

\section{Zielone}

14. Aksamitny galon bantajerowy z stułą y manipularz[em].

15. Adamaszkowy z kolumną Niebieską z stułą y manip[ularzem].

\section{Fioletowe}

16. Adamaszkowy w kwiaty złote z stułą y manipul[arzem].

17. Kitayczany niebieski $[\mathrm{w}]$ kwiaty srebrne reparowany.

\section{Czarne}

17. Gradyturowany z kolumną Partzrową z stułą y manip[ularzem].

18. Aksamitny z stułą y manipularzem.

\section{Kapy}

Aksamitna z Łudanową Lisztwą ceglastą stara.

Łudanowa Turkusowa z Lisztwą Lamową bialą stara. 
Fioletowa aksamitu strzyżonego z Lisztwą Tabinkową.

Czarna aksamitna $\mathrm{z}$ Lisztwą fioletowa.

${ }^{26}$ Partyrowa $\mathrm{w}$ rozne kwiaty ${ }^{27} \mathrm{z}$ Lisztwą kitayczaną w paski.

${ }^{28}$ Gradyłurowa Biała w kwiaty złote z lisztwą karmuzono|wą. Te obie ieszcze nie wszytkim skonczone:

Dalmatyki Partyrowe w kwiaty rozne z stułami y Manipularzami. Y te nieckonczone.

$<10>$

\begin{tabular}{|c|l|c|c|c|}
\hline \multirow{4}{*}{} & & Vela & Bursae & Pallae \\
\cline { 2 - 5 } & Albi & 8 & 7 & 8 \\
\cline { 2 - 5 } Coloris $^{\mathrm{b}}$ & Rubri & 11 & 6 & 16 \\
\cline { 2 - 5 } & Viridis & 2 & 1 & 6 \\
\cline { 2 - 5 } & Violacei & 10 & 8 & 12 \\
\cline { 2 - 5 } & Nigri & 3 & 3 & 6 \\
\cline { 2 - 5 } & In Sum[ma] Sztuk & 34 & 25 & 48 \\
\hline
\end{tabular}

\begin{tabular}{|l|c|}
\hline Korporatów płotna Szwabskiego & osim \\
\hline Tkackiego & osim \\
\hline Pasków & pięc \\
\hline Komzy płotna Szwabskiego & 16 \\
\hline Puryfikaterzow dawnieyszych & 10 \\
\hline tkackich & 6 \\
\hline Humerałow dawnieyszych & 2 \\
\hline nowych Szwabskich & 4 ale stare \\
\hline tkackiego & 6 \\
\hline Komeszek dla chłopcow & 1 \\
\hline Alby Hollenderskiego Płotna z koruną złotą & 4 stare \\
\hline Tkackiego & 1 \\
\hline nowa Szwabska & 8 \\
\hline Tuwalen roznych & 4 \\
\hline Obrusow lepszych & 6 \\
\hline starych & 2 \\
\hline Ręcznikow zakrzstyunych & 4 \\
\hline Ołtarzowych & 1 \\
\hline Antepedia Tabinkowe czerwone & \\
\hline
\end{tabular}

${ }^{\mathrm{b}}$ Kierunek tekstu - od góry do dołu.

${ }^{26}$ Dodatkowa uwaga nowe.

${ }^{27}$ Kwiaty jest poprzedzone przekreśleniem $\boldsymbol{w}$.

${ }^{28}$ Dodatkowa uwaga nowe. 


\begin{tabular}{|l|c|}
\hline stare & 1 \\
\hline nowych & 3 \\
\hline
\end{tabular}

\section{Miscellanea}

\begin{tabular}{|l|}
\hline Obraz Najśw[iętszej] [Maryi] Panny do noszenia pod czas Processyi cum suis requisitis. \\
\hline Statua Ukrzyżowanego P[ana] Jezusa na balce posrzod kościoła. \\
\hline Zma[r]twychwstalego Pana. \\
\hline Krzyż Processionalny. \\
\hline Baldachin Partyrowy nowo sprawiony. \\
\hline Chorągwi starych 5 Szosta Czarna nowsza. \\
\hline Całunow 2 ieden czarny Sukna podłego z krzyżem białym płociennym \\
\hline drugi czerwony iedwabny obszyty płotnem. \\
\hline Dywanow do Obicia Scian dużych starych dwa. \\
\hline Zasłonek do S[więtego] Thadeusza basztowych iedwabiem wyszywanych \\
\hline do S[więtego] Antoniego kitayczanych rozowego koloru \\
\hline starychy niezgodnych zielonego koloru \\
\hline kitayczana czerwona
\end{tabular}

$<10 \mathrm{v}>$

\section{Obligationes}

1. Ex mente Ill[ust]r[issi]mi Fundatoris: alere duos Vicarios actu Presbyteros, et Cantorem cum 2bus Sociis.

2. Festis duplicibus Fori et Chori Missam cantatare cum Vespe|ris 1mis et 2 dis.

3. Festis 1mae Classis Matutinum Deniq[u]e Cura anima de Jure consveto.

4. Pro animabus Fundatorum Missa Una Feria 2da

5. Pro Benefactoribus Vivis et Defunctis

$$
\text { a[1]tera Feria 3tia }
$$

\section{Missa Una Feria 5ta} altera Sabatlio

6. Pro augmento Ecclessiae Catholicae et Ne|cessitatibus occurrentibus

Missa 2dum Officium

7. Vigore Legationis Joannis Kaznowski Missa Menstrualis.

Hae omnes Obligationes absolvuntur.

8. Ad Altare S[ancte] Annae Missae duae in qualibet Septimana ex fundati|one Vilhelmi Klatt ${ }^{29}$ in Summa Sex Millium florenorum Monetae argenteae,

${ }^{29}$ Wilhelm Klatt - proboszcz parafii Rzeczyca, pochodzący z parafii Lachowicze. W testamencie ofiarował pieniądze na ołtarz. 
computando Talerum florenis sex locatorum in Bo|nis Wiedzma ${ }^{30}$ Cum onere ut pro his procuretur Praediolum (ad aler|dum Altaristam Lachovicensem), loco cuius olim currebat Census per octo a Centum, et adimplebatur Obligatio, nune vero cessante Benaficio, cessavit et Officium, Haec Altaria $\mathrm{ab}$ an|nis 19 ivit in oblivionem, quae nisi Strepitu Juris recuperabitur ${ }^{31}$.

Regit hanc Ecclesiam Benedictus Nornicki Theologus absolutus gnarus tatum Lingvae Polonicae et Latinae, Baprizatus Wołmae ${ }^{32}$ 1711. Post acceptas Literas dimissoriales cum Reditu ad propriam Diecaesim ab Ill[ust]r[issi]mo E[xcellentissimo] [ac] R[everendissimo] D[omino] Michaele Zienkowicz ${ }^{33}$ Loci Ordinario Promotus est ad 1mam Tonsuram et 4 minores Ordines ab Ill[ustrissimo] E[xcellentissimo] [ac] R[everendissimo] D[omino] Francisco Ko|bielski ${ }^{34}$ Ep[isco]po Antinopolitano, Suffraganeo Vladislav[iensi] Varsaviae 1732 ad Subdiaconatum, Diaconatum, et Presbyteratum ab Ill[ustr[issimo] E[xcellentissimo] [ac] R[everendissimo] D[omino] Jo|sepho Olszanski ${ }^{35}$ Ep[isco]po Serrensi, Suffraganei Chełmensi Brestiae 1734. Praesentotus ad praesens Beneficium ab Ill[ustrissimo] M[agno] D[omino] Georgio Sapieha Pala|tino ${ }^{36}$ Mscisłav. Institutus sub die 28 Julij Anno D[omi]ni 1743. Ab Ill[ust]r[issi]mo E[xcellentissimo] [ac] R[everendissimo] D[omino] Michaele Zienkowicz Ep[isco]po Vilnensi, est approbatus etiam a Casibus reservatis. Incedit vestitu decenti cum Collaribus et Tonsu|ra, habet non modo Rubricellam hujus Anni, Breviarium, Sed et quos te|netur habere Libros, et alios plures. Item reperiuntur Libri: Baptisa|torum, Copulatorum, Mortuorum, Parochianorum Omnium, cum Expre|ssione Nominum et Cognominum fingularum Personarum in sua Parecia degentium ${ }^{37}$.

\section{$<11 \mathrm{v}>$}

Koscioł $^{38}$ drewiany pod tytułem S[wętego] Krżyża Roku 1741 Erigowany ${ }^{39}$, na ktorym Kosciele wież dwie, a na koncu kopuł|ka iedna, w tym Kosciele Oltarżow pięć.

1 mo Ołtarż ${ }^{40}$ wielki snicerskiey roboty cum Immagine Cru|cifixi, z podmurowaniem, na tym Ołtarżu Cyborium snicer|skiey prżedniey roboty w ktorym con-

${ }^{30}$ Wiedzma - rzeka, która przepływa przez Lachowicze. Lewy dopływ Szczary. Również Wiedzma to osada na tej rzece, która później została przemianowana na Nowosiółki.

${ }^{31}$ Testament Wilhelma Klatta przechowywany w Bibliotece Uniwersytetu Wileńskiego (sygn. F5-A52-9546-9547).

${ }^{32}$ Wołma - miasto w powiecie mińskim, województwie mińskim.

${ }^{33}$ Michał Jan Zienkowicz (1678-1762) - kanonik wileński i archidiakon żmudzki (do 1718 r.); sufragan żmudzki (1718-1730); biskup wileński (1730-1762).

${ }^{34}$ Franciszek Antoni Kobielski (1679-1755) - biskup pomocniczy włocławski (1725-1736); biskup kamieniecki (1736-1739); biskup łucki (1739-1755).

35 Józef Olszański (1685-1738) - biskup pomocnicy chełmski (1727-1738).

${ }^{36}$ Pisarz miał na myśli Jerzego Felicjana Sapiehę (1680-1750), który był wówczas wojewodą mścisławskim

${ }^{37}$ Następnie jedną pustą stronę.

${ }^{38}$ Od tego momentu tekst pisany jest drugą ręką, mocniejszym naciskiem na papier.

${ }^{39}$ Tak w rękopisie.

${ }^{40}$ Litera $\dot{z}$ w słowie Oltari jest renderowana jako 3. 
servatur Venerabile w Puszce srebrney zewnątrz y zużerżchu dobrże pozłocaney, nad ktorymi w drugiey kondignacyi Statua snicerskiey robo|ty Boga Oyca w obłokach, do ktorego Ołtarza wszy[s]tkie requisita do mszy znayduią się. Po prawey stronie

2do Ołtarż Swiętego Ducha snicerskiey roboty stary czę|scią posrżebrżany y pozłocany, w gorże Obraz Boga Oyca malowany ${ }^{41}$ requisita zas wszystkie maiący do mszy. Po le|wey strone

3tia Ołtarż S[więtego] Thadeusza nowy snicerskiey prżedniey robo|ty w ktorym Obraz malowany, wszelkie requisita maiący do mszy, adąć na Koscioł

Kratki stolarskiey roboty w ktorych drzwi stworżyste na za|wiasach, żelaznemi prętami zmocnione, nad tymiż

Ambona stolarskiey roboty fugowana, za ktorą po prawey ręcę

Ołtarż czwarty z dwuma Kondignacyami snicerskiey roboty mieyscoma malowany y posrżebrżany. W pierwszcy Kondigna|cyi Obraz S[więtego] Antoniego, trżymaiący na lewey ręcę JEZUSA malenkiego, w drugiey Obraz S[więtego] Kazimierża, requisita wszy[s]t|kie maiący do $\mathrm{mszy}^{42}$. Po lewey ręcę

5to Ołtarż $\dot{z}^{43} \operatorname{takoz}^{44} \mathrm{z}$ dwuma kondignacyami mieyscoma malowany y posrżebrżany. W pierwszey kondignacyi Obraz S[więtey] Anny; Nayswiętszey Panny y JEZUSA maleńkiego, w drugiey Obraz nayswiętszey Panny Częstochowskiey z wszy[s]tkiemi prżynależytosciami do mszy. Przy tym Ołtarży

Babtisterium stolarskiey roboty w ktory woda w razie cynowey z nakrywką do Chrzszczenia staroswieckiey roboty akkomodowanie, $\mathrm{z}$ wierzchu y z dołu cyną, prżytym szafeczka ${ }^{45}$ zamczysta pro conservandis oleis Sacris

Posrżod Koscioła na belce Krżyż snicerskiey roboty cum effique Crucifixi

Item Krżyż mierny z passyą do używania pod czas processyi Konfessyonałow dwa stolarskiey roboty, ieden z prawey strony, drugi z lewey przy drzwiach. Nad tym

Chor ieden z balasami roboty stolarskiey, w ktorym

Ławek do siedzenia stolarskiey roboty $20^{46}$.

Laweczek $^{47}$ do siedzenia czasu słuchania spowiedzi 2.

Krżesło malowane suknem niebieskim obite.

Zakrystya po prawey ręce Ołtarża ${ }^{48}$ wielkiego, do schowania rżeczy koscielnych iako to, in primario. Obraz Nayswiętszey Panny do noszenia pod czas processyi, Statua Zmartwych wstałego Pana, Krżyż Processionalny;

\footnotetext{
${ }^{41}$ Pod linią jest napisane drugą ręką Ten Ottarz z kaplicy co w polu stoi przeniesiony do Koscioła.

${ }^{42}$ Litera $\boldsymbol{z}$ w słowie $\boldsymbol{m s z y}$ jest renderowana jako 3.

${ }^{43}$ Litera $\dot{z}$ w słowie Oltar $\dot{z}$ jest renderowana jako 3.

${ }^{44}$ Litera $\dot{z}$ w słowie tako $\dot{z}$ jest renderowana jako 3.

${ }^{45}$ Litera $\boldsymbol{z}$ w słowie szafeczka jest renderowana jako 3.

${ }^{46}$ Tutaj i dalej, gdy wskazana jest ilość, przed liczbą znajduje się znak №․

${ }^{47}$ Litera $\boldsymbol{z}$ w słowie Laweczek jest renderowana jako 3.

${ }^{48}$ Litera $\dot{z}$ w słowie Oltar $\dot{z}$ jest renderowana jako 3.
} 
Zakrystya po lewey ręce takoż ${ }^{49}$ Ołtarża wielkiego, w ktorey szafa do ubierania się do mszy z szafladami do schowania Monstracyi, Kielichow, Burs, Welow, Latek, Karporałow, Luryfikaterżow ${ }^{50}$ et c[etera].

Drywi wsyzstkich w ty[m] Kosciele 9. Dwoynych dwoie z tych iedne dębowe dubeltowe, a iedne sosnowe stolarskie[y] roboty fugowane, poiedynkowych w wieżach czworo, w zakrystyach trzy, dwoie z zamkami wnętrznemi, przy iednych zszcep|ka, wszystkie na zawiasach.

Okien szkła dobrego w ołow oprawnych 10, mnięszych 4 w całym Kosciele.

Posacka z cegieł mieyscoma reparacyi potrżebuie. Pod tą

Sklepow nowo murowanych 2. Ieden prżed Ołtarze[m] wielkim, drugi posrżodku Koscioła,

Cały Koscioł na podmurowaniu.

$<12-12 \mathrm{v}>$

Argenteria $\{\ldots\}$

$<12 \mathrm{v}>$

Vota Srebrne $\{\ldots\}$

$<12 \mathrm{v}-13>$

Kruszec $\{\ldots\}$

$<13-14>$

Paramenta $\{\ldots\}$

$<14>$

Miscellanea $\{\ldots\}^{51}$

$<14>$

Xięgi

\begin{tabular}{|l|l|l|}
\hline Mszałow starych 2, nowy ieden & 3 & \multirow{2}{*}{$\begin{array}{l}\text { Mszalikow Requialnych: dawnieyszy } 1 \\
\text { nowo kupionych 2c }\end{array}$} \\
\hline Agendek małych & 2 & \\
\hline Ewaneliczka & 1 & \\
\hline Xiązka do wpisywania w bratswo ${ }^{\mathrm{d}, \mathrm{e}}$ & 1 & \\
\hline
\end{tabular}

${ }^{\mathrm{c}}$ Napisane drugą ręką.

${ }^{\mathrm{d}}$ Tak w rękopisie.

e W parafii istniało bractwo św. Anny (bardziej szczegółowo: В. Камунтавічэне, Каталіцкія парафіi слонімскага дэканата віленскага біскупства ў XVII ст., Беларускі гістарычны агляд = Belarusian historical review, 11 (2004) Сш. 1-2, s. 151.)

${ }^{49}$ Litera $\dot{z}$ w słowie takoz jest renderowana jako 3.

${ }^{50}$ Litera $\dot{z}$ w słowie Luryfikaterżow jest renderowana jako 3.

${ }^{51}$ Sekcje „argenteria”, „vota srebrne”, „kruszec”, „paramenta”, „miscellanea” są powtarzane dosłownie. 


\begin{tabular}{|c|c|c|}
\hline Chorowe graduł & 1 & \multirow{5}{*}{$\begin{array}{l}\text { Te księgi wszystkie są podarte, nowych } \\
\text { dosta|wac trudno gdy nie dru|kuią } \\
\text { w Wilnie }\end{array}$} \\
\hline Antyfonarż & 1 & \\
\hline Psałterz & 1 & \\
\hline Processionał & 1 & \\
\hline Agend wielkich & 2 & \\
\hline
\end{tabular}

$<14 \mathrm{v}>$

PLEBANJA

Rum gontami pobity z drżewa sosnowego, do ktorego wchodząć ganek na słupach szesćiu, do sień drzwi na zawiasach, z klamką, zaszczepką z zasuwką żelazną po prawey ręce do izby drzwi stolarskiez roboty malowa|ne fugowane $\mathrm{z}$ klamką zaszczepką antabą y kruczkami zelaznymi, w izbie kominek murowany, piec kaflowy zielony, okien trży w drżewo oprawnych szkła nalibockiego ${ }^{52}$ sciany papierem kleione y pobielane. $Z$ tey izby

Drzwi do komory na zawiasach fugowane y malowane z zaszczepką y kruczkiem żelaznym. Okno iedne w drżewo oprawne szkła nalibockiego. $Z$ tey komory

Drzwi do spiżarni na zawiasach $\mathrm{z}$ zaszczepką, okno małe w drewno ${ }^{53}$ oprawne, z tey spiżarni drzwi do sień na zawiasach z zaszczepką. Naprżeciwku

Izb dwie, do ktorych drzwi na zawiasach z klamkami za|szczepkami y Kruczkami, piec iedna wobudwuch z ka|fel kominkow murowanych dwa okien cztyry w drewno oprawnych szkła ${ }^{54}$ nalibockiego, stoli y podlogi z tarcic rzniętych, kominow murowanych dwa nad dach wyprzowadzonych, między ktoremi drabina na dachu. W teyże plebanij a parte

Budynek, do ktorego sień wchodząć drzwi na biegunach w sieniach Kuchnia, po prawey ręce

Izba do tey drzwi na zawiasach z klanką y kruczkiem ${ }^{55}$. Piec kaflowy zielony, okno iedne większe, małych dwa w drewno opracowne szkła roznego, stol y podloga z tarcic. Naprżeciwku takoż

Izba, do ktorey drzwi na zawiasach z klamką y krucz|kiem, z piecem kaflowym zielonym y do pieczenia chle|ba murowanym, okno iedne, większe, drugie malę $\mathrm{w}$ drewno oprawne, szkła roznego. Stol z tarcic pod|łoga gliną wybiana, komin ieden murowany y nad dach wyprowadzony, prży tey izbie

Swiranek. Do tego drzwi na biegunach z zaszcepką, stol z tarcic, podłoga gliną wybijana. Zatym

Staynia, do tey drzwi z dranic na biegunach z zaszcep|ką, podłoga z drzewa ciesanego. Cały ten Budynek z swironkiem, staynia pod iednym dachem dranicami krytym, prży tym piwnica nowo stawiona gontami pobita, za tym budynkiem

Wozownia nowo stawiona dranicami krzyta prży tey

\footnotetext{
${ }^{\mathrm{f}}$ Napisane drugą ręką.

${ }^{52}$ Autor ma na myśli fabrykę szkła książąt Radziwiłłów w Nalibokach (powiat miński, województwo mińskie).

${ }^{53}$ Tak w rękopisie.

${ }^{54}$ Tak w rękopisie.

${ }^{55}$ Litera $\boldsymbol{z}$ w słowie $\boldsymbol{k r u c z}$ kiem jest renderowana jako 3.
} 
Studnia ocembrowana z zurawię nową.

Cała plebania y Kośćioł oprkaniona drżewe[m] piłowan[ym] częscią okrą[g]łym. $<15>^{56}$

\section{SZPITAL}

Brusowany gontami pobity, prży tym ganek na cztyrech słu|pach, w ktorym izb dwie z komorami, do nich drzwi na zawiasach troie item na biegunach troie, piec z kafel szarych, y krżyżowe do pieczenia chłeba okien szkła okrą|głego. Większych "4" 57 , małych dwa, stol z tarcic, podłoga gliną wybiana. Nieda[le]ko szpitali częsć łąki wydziełona dla koni, któremi do chorych jędzą.

JURYZDYKA, na ktorey mieszkaią

\begin{tabular}{|l|c|}
\hline Theodor Kwasinski & 1 \\
\hline Jan Szafranowicz & 1 \\
\hline Bohdan Tatarżyn & 1 \\
\hline Michał Borysewicz & 1 \\
\hline Josef Niewirowski & 1 \\
\hline Mucha[mad] Tatarżyn & 1 \\
\hline Bartłomiey Romeyko & 1 \\
\hline Jesman Tatarżyn & 1 \\
\hline Wasil Koncewicz & 1 \\
\hline Pławski wdowa & 1 \\
\hline Michał Woyciechowski & 1 \\
\hline Szaban Tatarżyn & 1 \\
\hline Jankiel żyd & 1 \\
\hline Meier żyd & 1 \\
\hline Jerży Rokicki & 1 \\
\hline Jedwiga wdowa & 16 \\
\hline In Sum[m]a & 1 \\
\hline
\end{tabular}

Powinnosć tych juryzdyczanow

1 mo Czynsz z krotszych ogrodow dac maią zł[o]t[ych $]^{58} 2$.

2 do z dłuższych zł[o]t[ych $]^{59} 4$.

3tio do żniwa tłok pięć po iednemu $\mathrm{z}$ domu.

4to warta pod wuch koleyno do Kościoła

5to z processyami y listami nay daley o mil pięć cho|dzić koleyno powinni.

${ }^{56}$ Część tekstu na arkuszu charakteryzuje się obecnością ciemnych aureoli wokół pociągnięć tuszem.

${ }^{57}$ Tak w rękopisie.

${ }^{58}$ Litera $z$ w słowie zł[o]t[ych] jest renderowana jako 3.

${ }^{59}$ Litera $z$ w słowie $\mathrm{zł}[\mathrm{o}] \mathrm{t}[\mathrm{ych}]$ jest renderowana jako 3. 
$<15 \mathrm{v}>$

Folwark Hruszowka ${ }^{60}$ cum attinenciys

Rum mieszkalny przed którym ganek; do sien wschodząc drzwi na zawiasach z klamkę y zaszczepką w tym po prawey ręce

Izba, do niey drzwi na zawiasach, kominek murowany, piec z kafel zielonych. Okien trzy szkla nalibockiego w dembowe oprawne drzewo. Item, drzwi idąć do kaplicy na zawiasach w tey okien dwie w drewno oprawnych, daley drzwi do komory na zawiasach z zaszczepką y zasuwką; okno iedne ze szkłem nalibockim z tey drzwi, do spiżarni na zawiasach z zaszcepką, okno iedne szkła nalibockiego na prżeciw

Izba z komorą drzwi dwoie na zawiasach, piec kaflowy zeilony, okien "4" szkła nalibockiego w tym Rumie, podlogi z gliny wybijane, w kaplicy z tarcie rzniętych cały gontami pobity z kominami dwuma murowanemi, na ktorym drabina. Na przeciw tego

Dom gospodarski wpół gontami wpuł ${ }^{61}$ dranicami kryty. Do tego sień drzwi drzwi ${ }^{62}$ na biegunach wchodząc do izby drzwi na zawiasach z klamką [y] zaszcepką. Y an|tabą w Izbie kominek murowany z kominem nad dach wyprowydzonym, piec kaflowy zielony z piecem krżyżowym do pieczenia chleba, okien trzy szkła nalibockiego, $w$ drewno oprawne $z$ tey izby drzwi dwoie

Do alkierza y spieżarni na zawiasach z zaszczepkami okien dwa w drewno oprawne szkła nalibockiego, w spie|żarni mnieysze szkła prostego z tey drzwi

Do komory na biegunach okno iedne szkła nalibockiego, z komory drzwi do bokówki na biegunach, do izby na za|wiasach, z zaszczepką. W bokówce zas okno iedne szkła prostego, z ktorey drzwi do sień na biegunach. Stoli z tarcic podłogi gliną wybijanę, do kuchni drzwi na biegunach, w ktorey komin pleciony prosto

Piekarnia z komorką, drzwi do niey na biegunach. W Izbie okien trzy szkła prostego, w komorze iedno. Stol z deszcek ciesanych, podłoga $\mathrm{z}$ gliny wybijana na tey drabina aż do samego komina; in medio podworża

Syrnik gontami pobity za ktorym

Browar z osoecią dranicami kryty. Do Browaru wróta z dranic na biegunach z zaszczepką y kluczem przez szutą żelaznym.

$<16>^{63}$

Do osieci drzwi na biegunach z tarcic z piecem kamien|nym. Okien w osieci małych dwa, ze szkła prostego, stol z tarcic cały dranicami kryty, przy ktorym karmnik dla swiń słomą kryty.

Studnia ocembrowana z zurawiem. Od tey

${ }^{60}$ Litera $\boldsymbol{z}$ w słowie Hruszowka jest renderowana jako 3. Folwark Hruszowka znajdował się w odległości $5 \mathrm{~km}$ na południowy wschód od Lachowicz.

${ }^{61}$ Tak w rękopisie.

${ }^{62}$ Powtórzenie w rękopisie.

${ }^{63}$ Część tekstu na arkuszu charakteryzuje się obecnością ciemnych aureoli wokół pociągnięć tuszem. 
Wyrżywnia z drewa okrągłego, z obudwuch strón hle[w]ki, drzwi do nich na biegunach y dranic, pod iednym słomą kryciem, z obudwuch stron przy Punie

Piwnic dwie gontami zobite drzwi na biegunach z zaszczepkami z stolą drzewa ciesanego iedna nowa wystawiona; pryz tey

Swironek y szpichlerz drzwi troie na zawiasach z za|szczepkami żelaznemi, stol y podłoga z tarcic, dranicami kryte. Daley

Staynia z drzewa okrągłego słomą kryta, przy ktorey

Obora z drzewa okrągłego wrót na biegunach "6" słomą kryta. Prosto tey

Gumno nowo stawione na sochach sosnowych " 22 ". W tym wrot dwoistych dwoie, iedne $\mathrm{z}$ tarcic, drugie $\mathrm{z}$ dranic poiedynkowych, dwoie $\mathrm{z}$ dranic na biegunach, troie kołkami ze srżodku zamykaią się. Przy czwartych klamka prżez drąg $\mathrm{z}$ zamkiem wiszącym, prży ty[m] na rogach odryn dwie z drżewa okrągłego $\mathrm{w}$ tych wrót dwoie $\mathrm{z}$ dranic, iedne $\mathrm{z}$ zasuwką drewianą $\mathrm{z}$ tworżyste $\mathrm{z}$ tarcic na biegunach $\mathrm{z}$ kalamką y zamkiem wiszącym, w drugiey takoż wrót dwoie z dranic, $\mathrm{z}$ zasuwkami drewnianemi z gumnem pod iednym nakrżyciem słomą. Całe to zabudowanie oparkanione częscią drżewem okrągły[m], częscią kołami, w którym wrót dwoie $\mathrm{z}$ dranic na biegu|nach stworżyste do Lachowicz ${ }^{64}$, poiedynkowe do Koniuchow.

Bydło rogate y inne w tym folwarku będęce.

\begin{tabular}{|l|c|}
\hline Krowa doyna & 1 \\
z cielęciem sztuk & 2 \\
\hline Jałowychy wypustkow tak rocznych & 2 \\
\hline Byczkow & 3 \\
\hline \multicolumn{2}{|c|}{} \\
\hline wołów & Summa sztuk 8 \\
\hline Owiec starych 31 & Jagniąt 19 \\
\hline Swiń ogułem 15 & 13 \\
\hline Ptastwo domowe 10 \\
\hline Gęsi starych & 6 \\
\hline Indykow ogułem & 10 \\
\hline Kaczek z kaczorami & 3 \\
\hline Kur starych z kogutem & 2 \\
\hline Kapłunow & \\
\hline
\end{tabular}

$<16 v>$

Zasiew w tym folwarku zboża różnego

\begin{tabular}{|l|c|c|}
\hline & \multicolumn{2}{|c|}{ Zboże różne } \\
\hline & korcy & cwier[ci] \\
\hline Zyta w roku 1752 na Rok 1753 posiano & 30 & \\
\hline
\end{tabular}

g Pisarz się mylił. Musi być roku 1742 na rok 1743.

${ }^{64}$ Litera $\boldsymbol{z}$ w słowie Lachowicz jest renderowana jako 3. 


\begin{tabular}{|l|c|c|}
\hline Jarki & 1 & \\
\hline Grochu & 1 & \\
\hline Bobu & & 2 \\
\hline Pszenicy Jarey & 1 & \\
\hline owsa & 30 & \\
\hline jączmienia & 13 & \\
\hline konopi & & $1 / 2$ \\
\hline Lnii & & $2^{1 / 2}$ \\
\hline konopi & & $1 / 2$ \\
\hline Gryzi & 7 & \\
\hline
\end{tabular}

\section{W tymże folwarku}

\begin{tabular}{|l|c|}
\hline Naczynie rózne gospodarskie & 10 \\
\hline Keczek piwnych & 10 \\
\hline Cebrow cztery do noszenia wody & 4 \\
\hline Wiader dwa & 2 \\
\hline Dzieża do pieczenia chleba & 1 \\
\hline Korcow do mierżenia zboża & 2 \\
\hline Czwiertek & 2 \\
\hline Mechi & 2 \\
\hline Fas do zfypania zboża starych & 7 \\
\hline Łotek stary w korcy szesć & 1 \\
\hline Wanna stara, szuflow dwa & \\
\hline Stoł ieden w Rumie nowym & 1 \\
\hline Stoł drugi w tymże Rumie w drugiey izbie & 1 \\
\hline Stoł trzeci w sieniach & 1 \\
\hline Stołkiw & 6 \\
\hline Łożek & 3 \\
\hline Naczynie browarne & \\
\hline Kocioł miedziany z strąbami y przytrąbkami & 1 \\
\hline Czapka do niego gliniana & 1 \\
\hline czopów & 2 \\
\hline spustnik & 1 \\
\hline Hołowicznik do zadania brahi z piwa & 1 \\
\hline trąbnica & 2 \\
\hline Beczka wodczana & 1 \\
\hline Ryn 2, czerpach & 1 \\
\hline
\end{tabular}


$<17>65$

Inwentarz poddanych wsi Potapowicz ${ }^{66}$

\begin{tabular}{|c|c|c|c|c|c|}
\hline Gospodarze & $\begin{array}{l}\text { Grunt osadzcy } \\
\text { czwieci włoki }\end{array}$ & & syny & woły & konie \\
\hline 1 & 2 & $\begin{array}{l}\text { Michał Drozd, syn Wawrzyniec, } \\
\text { wnuk Maciey }\end{array}$ & 1 & 2 & 1 \\
\hline 2 & 1 & Jan Sliwa, Syn Thadeusz & 1 & 1 & \\
\hline 3 & 2 & $\begin{array}{l}\text { Antoni Sliwa, synow } 2 \text { Bazyl } \\
\text { y Maciey }\end{array}$ & 2 & 1 & 1 \\
\hline 4 & 2 & $0^{\mathrm{h}}$ & & & \\
\hline 5 & 2 & Kazimierz Chmaruk, Dominik syn & 1 & & 2 \\
\hline 6 & 1 & Jurko Chmaruk, syn Michał & 1 & 2 & 1 \\
\hline 7 & 1 & Stefan Chmaruk, syn Michał & 1 & 2 & 1 \\
\hline 8 & 2 & Kazimierz Firus, syn Andrzey & 1 & 1 & 2 \\
\hline 9 & 1 & $\begin{array}{l}\text { Tomacz Bogdanowicz, pasierb } \\
\text { Kasper }\end{array}$ & & 1 & 1 \\
\hline 10 & 1 & Agata Immanowa & & 1 & 1 \\
\hline 11 & 1 & Michał Chmaruk, syn Kazimierz ${ }^{\mathrm{i}}$ & 1 & 1 & 2 \\
\hline 12 & 1 & $0^{\mathrm{j}}$ & & & \\
\hline 13 & 1 & Jan Popko, syn Franciszek & 1 & 1 & \\
\hline 14 & 1 & $\begin{array}{l}\text { Leon Kucharczyk }{ }^{k} \text {, syny Grzegorz, } \\
\text { Maciey, Jakub, Stefan }\end{array}$ & 4 & 1 & \\
\hline 15 & 2 & Jozef Imun & & 2 & \\
\hline 16 & 2 & Jan Rugin, szwagier Maciey & & 1 & 1 \\
\hline 17 & 1 & Szymon Dubrowka, syn Kazimierz & 1 & 1 & 2 \\
\hline 18 & 1 & $0^{1}$ & & & \\
\hline 19 & 1 & Piotr Sołowiey, zięc Michał & & & \\
\hline 20 & 1 & $\begin{array}{l}\text { Jakub Firus, syny Michał, Jerzy, } \\
\text { Kazimierz }\end{array}$ & 3 & 1 & 1 \\
\hline 21 & 1 & Michał Kuraczycki & & 1 & 1 \\
\hline 22 & 1 & Jozef Remeyko & & 1 & \\
\hline 23 & 1 & $\begin{array}{l}\text { Michał Remeyko, syny Wawrzyniec. } \\
\text { Jozef, Piotr }\end{array}$ & 3 & 2 & 1 \\
\hline
\end{tabular}

h Tak w rękopisie.

${ }^{\mathrm{i}}$ Litera $\mathrm{z}$ w słowie Kazimierz jest renderowana jako 3.

${ }^{\mathrm{j}}$ Tak w rękopisie.

${ }^{\mathrm{k}}$ Litera z w słowie Kucharczyk jest renderowana jako 3.

${ }^{1}$ Tak w rękopisie.

${ }^{65}$ Część tekstu na arkuszu charakteryzuje się obecnością ciemnych aureoli wokół pociągnięć tuszem.

${ }^{66}$ Wieś Potapowicze znajdowała się w odległości 3 km na wschód od Lachowicz. 


\begin{tabular}{|c|c|l|c|c|c|}
\hline 24 & 1 & $\begin{array}{l}\text { Lawryn Remeyko, syny Jan, Jerzy, } \\
\text { u Jana syn Dominik }\end{array}$ & 2 & 2 \\
\hline 25 & 1 & Kan Dubrowka & & & \\
\hline 26 & 1 & $\begin{array}{l}\text { Piotr Łoyko, Pasierby Stanisław y } \\
\text { Franciczek }\end{array}$ & 1 & \\
\hline 27 & 1 & Michał Winnik, brat Paweł & & 1 & 1 \\
\hline 28 & 1 & $\begin{array}{l}\text { Jurko Demid, syny Bartołomey y } \\
\text { Krzys[ztof] }\end{array}$ & 2 & & 1 \\
\hline 29 & 1 & Szymon Kuraczycki & Sum[a] & 24 & 20 \\
\hline
\end{tabular}

$<17_{\mathrm{v}}>$

Opisanie Folwarku Dworu Koniuchow ${ }^{67}$

W tym Folwarku budynek nowo prżestawiony w poł dra|nicami w puł słomą kryty, izba z komorą, piec kaflo|wy zielony z kominkiem murowanym. Okien w tey izbie dwa ze szkła nalibockiego, w komorże iedne do izby z komory drzwi na zawiasach drugie na biegunach, $\mathrm{z}$ komory do spiżarni

nowo stawioney drzwi na biegunach z zaszczepką w ktorey okno małe prżez sien piekarnia nowo stawiona, piec piekarny zwyczayny, okien małych 4 szkła okragłego. Prżeciw tego domu studnia nowo wykopana y ocembrowana, z żurawie[m]. Chlew dla bydła nowo stawiony, do tego wrót troie z dranic na biegunach, słomą kryty, raze[m] złączony. Swiren z zasiekami słomą kryty, drzwi na zawia|sach z zaszczepką y zamkie[m] wiszący[m]. W bliskosci tego gumno wielkie na dyiesięciu sochach, wrot dwoi|stych dwoie, iedne zewnątrż kołkiem się zamy|kaiąć, drigue z klamką alias zaszczepką z za[m]kiem wiszącym. W tymże swireń do szypowania zboża, drzwi na biegunach z zaczczepką. Prżytymże gumno nowe na sochach, wrot dwoie na biegunach iedne zesrżodka zamykaią się drugie z zaszczepką y zam|kiem wiszącym. Cale to zabudowanie cząscią par|kanem częscią płotem oparkanione.

Żyta kor[cy] 50, jęczmienia kor[cy] 8, owsa kor[cy] 16, gryki korcy 12, pszenicy korcy dwa.

$<18>68$

Inwentarz poddanych wsi Koniuchow

\begin{tabular}{|c|c|l|c|c|c|}
\hline Gospodarze & $\begin{array}{c}\text { Grunt osadzcy } \\
\text { czwieci włoki }\end{array}$ & syny & woły & konie \\
\hline 1 & 2 & $\begin{array}{l}\text { Ihnat Loyko, syny Andrżey, } \\
\text { Krzy[sztof] }\end{array}$ & 2 & & 2 \\
\hline 2 & 2 & Jan Bohdanowicz & & & 2 \\
\hline 3 & 2 & Andrżey Bohdanowicz & & & \\
\hline
\end{tabular}

${ }^{67}$ Folwark Koniuchy znajdował się 9 km na wschód od Lachowicz.

${ }^{68}$ Część tekstu na arkuszu charakteryzuje się obecnością ciemnych aureoli wokół pociągnięć tuszem. 


\begin{tabular}{|c|c|c|c|c|c|}
\hline 4 & 2 & $\begin{array}{l}\text { Daniło Sokoł, synow } 2 \text { Andrżey y } \\
\text { Jozef }\end{array}$ & 2 & 2 & 1 \\
\hline 5 & 2 & $0^{\mathrm{m}}$ & & & \\
\hline 6 & 2 & $\begin{array}{l}\text { Franciszek Remeyko, syny Jan y } \\
\text { Michał, Mateusz }\end{array}$ & 3 & & \\
\hline 7 & 2 & Jurko Czeleiewicz, syn Stanisław & 1 & & 1 \\
\hline 8 & 2 & Maciey Szrubeyko, syn Piotr & 1 & 2 & \\
\hline 9 & 2 & Kasper Szrubeyko & & 1 & \\
\hline 10 & 2 & $0^{\mathrm{n}}$ & & & \\
\hline 11 & 2 & $\begin{array}{l}\text { Kasper Łoyko, syny Paweł, } \\
\text { Theodor, Jakub }{ }^{\circ} \text {, zięc Andrżiey }\end{array}$ & 3 & 2 & 1 \\
\hline 12 & 2 & $\begin{array}{l}\text { Stasko Cyeliewicz syny Ignacy, } \\
\text { Michał }\end{array}$ & 2 & & 2 \\
\hline 13 & 2 & $\begin{array}{l}\text { Stasko Łoyko, syn Jozef, brat } \\
\text { Dominik }\end{array}$ & 1 & & \\
\hline 14 & 2 & $\begin{array}{l}\text { Thomasz Łoyko, syny Ignacy y } \\
\text { Michał }\end{array}$ & 2 & & 1 \\
\hline 15 & 2 & Franciszek Bubienczyk, syn Piotr & 1 & & 1 \\
\hline 16 & 2 & Jan Remeyko, syn Maciey & 1 & & 1 \\
\hline 17 & 2 & Ihnat Remeyko, syny Jozef, Leon & 2 & 2 & 1 \\
\hline 18 & 2 & $\begin{array}{l}\text { Mikołay Kiczyło, syny Kimrz, } \\
\text { Paweł, Stefan }\end{array}$ & 3 & & \\
\hline 19 & 2 & Michał Łoyko, synowiec Fabian & 1 & & 1 \\
\hline 20 & 2 & Dominik Remeyko & & 1 & 1 \\
\hline 21 & 2 & $\begin{array}{l}\text { Łukasz Remeyko, syny Jozef, } \\
\text { Michał }\end{array}$ & 2 & 1 & 1 \\
\hline 22 & 2 & $\begin{array}{l}\text { Lawryn Remeyko, syny Franciszek, } \\
\text { Jozef }\end{array}$ & 1 & & 1 \\
\hline 23 & 2 & $\begin{array}{l}\text { Jan Bayczyk, syny Franciszek y } \\
\text { Josef, y Franciszka syny Piotr y } \\
\text { Stefan }\end{array}$ & 2 & 2 & 1 \\
\hline $\mathrm{p}$ & 2 & Bazyl Kiczyło & & 2 & \\
\hline \multirow[t]{2}{*}{ q } & 2 & $0^{\mathrm{r}}$ & & & \\
\hline & & & Suma & 15 & 19 \\
\hline
\end{tabular}

m Tak w rękopisie.

${ }^{n}$ Tak w rękopisie.

${ }^{\circ}$ Imię Jakub znajduje się nad tekstem.

${ }^{\mathrm{p}}$ Nienumerowane w rękopisie.

${ }^{\mathrm{q}}$ Nienumerowane w rękopisie.

${ }^{\mathrm{r}}$ Tak w rękopisie. 
$<18 \mathrm{v}>$

Powinnosć Y ustawa ${ }^{69}$

Chłopow w tych wsiach mieszkaiących w każdy tydzień w zimie y w lecie z puł włoki z czym rażą dni trży wychodzić maią, a zosobna latem czasci zimwa cztyry gwałty odprawić powinni, na|straż tygodniową koleyną do plebaniy y folwar|ku chodzić maią. Osobliwie podwuch na warte noczną; na robote zaś wychodzić maią po w|schodzie słonca y aż do zachodu robić.

Prżytym powinni dawać z każdey puł włoki żyta puł beczeki ${ }^{70}$ owsa puł beczeki miary wilenskiey ${ }^{71}$ alias korżec dobrey miary. Kapłunow dwa a bo za dwuch gęś iedna, iaiec dziesęć, pszczoły u kogą, są miod prżez połowe na dwor ma być podbierany, puł woza siana, takze pieniędzmi gr[oszy] 15. Podwody naydaley o mil 30 z włoki po iedney.

Symmariusz wsystkiego ${ }^{72}$

\begin{tabular}{|l|}
\hline Gruntu w obudwuch wsiach osiadłego włok 20 czwierci 2 \\
\hline $\begin{array}{l}\text { Pustego [włok] } 2 \text { czwierci [2] } \\
\text { Sum[a] wł[ok] } 23\end{array}$ \\
\hline Pansczyzny tak męzkiey iako żonockiey ogulem wychodzi dni 123 \\
\hline Wołow inkludiąc y te, ktore się na zapomoge chłopom dały sztuk 39 \\
\hline Koni także razem w obudwuch wsiach znayduie się 49 \\
\hline Żyta dziakielnego miary Wilenskiey nalezy Beczek 20 y puł, czyni korcy 41 \\
\hline Owsa dziakielnego teyże miary [Beczek] 20 y puł, czyni k[orcy] 41 \\
\hline Siana rachuiąć z włoki po wozy, czyni nastramkow 41 \\
\hline Kurow rachuiąć z włoki po cztyry 82 \\
\hline Iaiec po dwadziescie, czyni 410 \\
\hline Korcowczyzny z miasta Lachowicz według funduszu korcy 40 \\
\hline Dziesięciny z Hrabstwa Lachowickiego nalezy kop 50 \\
\hline
\end{tabular}

Provent gotowym Groszem

\begin{tabular}{|l|c|c|c|}
\hline & złote & grosze & szeląg[y] \\
\hline Od mieyscan y żydow lachowickich z placu po puł 8 grosza: & & & \\
\hline Czynszu z Jurysdyki & & & \\
\hline Czynszu z obodwuch wsiow należy & 20 & 15 & \\
\hline Dziesięciny pienięzney z Hrabstwa Lachowickiego & 270 & & \\
\hline Od Kahalu Lachowickiego należy & $300^{s}$ & & \\
\hline
\end{tabular}

${ }^{\mathrm{s}} \mathrm{U}$ dołu strony znajduje się postscriptum $\mathrm{A}[\mathrm{no}] \mathrm{D}$ [o]m[ini] 1745.

${ }^{69} \mathrm{~W}$ rękopisie Yustawa.

${ }^{70}$ Tak w rękopisie.

${ }^{71}$ Beczka miary wileńskiej - 72 garnce Wielkiego Księstwa Litewskiego (litewskie), czyli 406,61 litra.

${ }^{72}$ Ten tekst został dodany inną ręką. 
$<19>$

$\mathrm{A}[\mathrm{nno}$ ] D[o]m[ini] 1745 mensis Julij Die 21. Praesens Inventarium Ecclesiae Parochiali Lachovicensi tempere G[e]n[era]li Visi|tatiemi Emidem Ecclesiae coram Nobi[s] Antonio Josepho Żołkowski Ep[isco]po Allaliensi, Suffraganeo Albae Russiae, Pr[a]elato Decano Cathedrali; Vicario in Spirit[ualibus] et Officiali Generali Vilnensi pro ductum, vidim[u]s legitimus, et manu propria connotarimus. [Actum in] damo [Plebnali] Lachovicensi a[nn]o mence, die ut supra.

A. J. Żołkowski Ep[isco]pus Allalien[sis] ut iminediate ${ }^{73}$.

$<20>$

\section{Decretum Reformationis}

Antonius Josephus Zołkowski DEI et Ap[osto]1[i]cae Sedis gratia Ep[isco]pus Allaliensis, Suffraganeus Albae Russiae, Pralatus Decanus Cathedralis, Vicarius in Spiritualibus, et Officialis G[e]n[era]lis Vilnensis Adm[inistratori] R[evere]ndo D[omi]no Benedicto Nornicki Parocho Lachovicensi, Circa Visitationem G[e] $\mathrm{n}$ [era]lem Ecclesiae Ipsius, infrascripta aliquod Puncta in vim Decreti adimplenda Intimavi Anno D[omi]no $1743^{74}$ Die 21 Julij.

1 mo Baptisterium decenter reparate, Clausuram ad illud appone|re, et claves tam a Cyborio, quam ab eodem Baptisterio apud se conservare Serio obligatur. Satisfactum.

2do Fundamentum Ecclesiae non pridem erectae suppositis lateribus fulcire quantociius curet, alias paenis contra non adimplentes Decreta Visitationis subjacebit. Satisfactum.

3tio Portatile novum ad majus altare procurare non negligat. Satisfactum.

Pro majori autem Praemissorum valore, et prompriore paucorum Injunctorum excetione Subscripsi. In quorum fedim Da|tum in Domo [Plebanali] Lachovicensi Anno, Mense, Die quibus Supra.

\section{REFERENCES / BIBLIOGRAFIA}

\section{Źródła archiwalne}

Biblioteka Uniwersytetu Wileńskiego. Dział Rękopisów

sygn. F5-A52-9546-9547, "W ymie Oyca y Syna y Ducha Swetego Amen...”. [Vilhelmo Klato, Rečycos pastalininkio, testamentas] 1728.

Narodowe Archiwum Historyczne Białorusi sygn. 937-3-8, “Инвентарь Ляховицкого костёла и прихода” 1828.

sygn. 937-3-11, “Инвентарь Ляховицкого костёла, прихода и фольварков” 1831.

sygn. 1738-1-1, “Актовая книга” 30.05.1793-23.12.1794.

sygn. 1781-27-213, “Визиты костёлов Западной Беларуси” 1745.

\footnotetext{
${ }^{73}$ Brakuje dołączenia pieczęci biskupiej. Następna pusta strona.

74 Pisarz się mylił. Wizyta odbyła się w 1745 r.
} 


\section{Źródła drukowane}

Synodus Dioecesana Vilnensis ab Illustrissimo, Excellentissimo ac Reverendissimo Domino D. Michaele Joanne Zienkowicz Dei \& Apostolicae Sedis Gratia episcopo Vilnensi, Vilnae: Typis Mandata, MDCCXLIV [1744].

Urzędnicy Wielkiego Księstwa Litewskiego. Spisy, t. 9: Województwo mścisławskie XVI-XVIII wiek, red. A. Rachuba, Warszawa 2019.

\section{Opracowania}

Bułaty Paweł Juriewicz, Uładanni i haspadarczaja dziejnasc katalickaha kascioła na ziemlach Lachawickaha hrafstwa (XVII-XVIII stst.), Wiesci BDPU Sieryja 2, (2018) №2, s. 96-100.

Bułaty Paweł Juriewicz, Pierszaja wizitacyja murawanaha kascioła u Lachawiczach (1804 hod), ,,Dothij XIX wiek” w istorii Biełarusi i Wostocznoj Jewropy, matieriaty III mieżdunarodnoj konfieriencii, s. 38-39.

Kamuntawiczenie Waida, Katalickija parafii słonimskaha dekanata wilenskaha biskupstwa u XVII st., Biełaruski histaryczny ahlad = Belarusian historical review, 11 (2004) Ssz. 1-2, s. 137-156.

Mietadycznyja rekamiendacyi da publikacyi łacinskich dakumientau XIII-XIV stst., skład. A. Żłutka, Mińsk 2012.

Mietadycznyja rekamiendacyi pa publikacyi polskamounych dakumientau pa historyi Bietarusi CHVI - pierszaj pat., komp. A. Shalanda, Mińsk 2012.

Wilczewski Waldemar F., Wizytacje generalne diecezji wileńskiej w XVII-XVIII w. Ewolucja problematyki, ,SOTER”, (2010) №2 35(63), s. 99-109.

Wilczewski Waldemar F., Spustoszenia wojenne w dekanacie słonimskim w czasie najścia moskiewskiego w połowie XVII wieku, „Nasza Przeszłość”, 94 (2000) s. 245-298.

\section{Netografia}

The Hierarchy of the Catholic Church. Current and historical information about its bishops and dioceses, https://www.catholic-hierarchy.org/ (dostęp: 18.03.2021). 
PARISH OF THE EXALTATION OF THE HOLY CROSS IN LACHOWICZE IN THE VISITATION DESCRIPTION FROM 1745

\begin{abstract}
The publication presents a visit to the parish of The Exaltation of the Holy Cross in Lachowicze on 31 July 1745. It was the first inspection after the renovation of the church, which was destroyed in 1706 during the Great Northern War. The temple was consumed by fires multiple times, it was confiscated after the January Uprising by the Tsarist authorities and destroyed by the authorities of the Belarusian Soviet Socialist Republic in 1960. Currently, the Church of The Exaltation of the Holy Cross, like the parish, does not exist. The presented text of the visitation was accompanied by a scientific and text commentary. The methodology of working with the manuscript was also presented.
\end{abstract}

Keywords: Lachowicze; Parish of the Exaltation of the Holy Cross; visitation; Antoni Józef Żółkowski; Belarusian suffragan dioces 